\title{
Fatal Car Occupant Injuries After Car/Lorry Collisions
}

\author{
WILLIAM GISSANE, JOHN BULL
}

British Medical fournal, 1973, 1, 67-71

\section{Summary}

All deaths from road accidents in certain areas and periods were studied. Analysis of 224 deaths to car occupants from collisions between cars and lorries showed that such accidents were the commonest cause of death for car occupants on motorways and link roads. The impacts were such that relatively poor protection could be given by occupant restraint systems. Collisions of cars into the rear of lorries caused the most severe injuries; most of these accidents occurred at night.

The traffic characteristics of cars and lorries are largely incompatible and increase the likelihood of collisions and of extremely severe injuries to car occupants. Some reduction in deaths may be expected from making lorries more conspicuous and eliminating the rear overhang. More fundamental measures are segregation of lorries from cars and return of traffic to railways.

\section{Introduction}

The first two deaths due to motor vehicles were registered in Great Britain in 1896. They were both pedestrians. During this century over 250,000 people have been killed on our roads, and as the numbers of cars have increased their occupants have replaced pedestrians as the main victims. One of the major factors now contributing to this state is the use of the same roads by cars and lorries. During the decade covered by this survey, cars have doubled in number (5.5 to 11.5 million) and most have remained small in size. The total number of lorries has not markedly increased (1.4 to 1.6 million) but those of 5 tons and over unladen weight have increased threefold $(42,000$ to 123,000$)$ and those of 8 tons and over unladen weight by fourfold $(11,000$ to 47,000 ). In view of the proposal that lorries of even greater size and with heavier loads might be permitted on our roads it is important to appreciate the implications in injury and death of this mixing of cars and heavy vehicles.

Road Injuries Research Group, Birmingham Accident Hospital, Birmingham 15

WILLIAM GISSANE, D.sC., F.R.C.s., Director

JOHN BULL, M.D., F.R.C.P., Director

\section{Method of Study}

By arrangements with the appropriate coroners, all fatal accidents to vehicle occupants in certain areas over specific periods were studied. Their records include police details of the circumstances of these accidents with diagrams of the position of vehicles, occupants, etc., together with necropsy findings on all but 10 of the fatal cases. Many of the sites of the fatal collisions were examined by us, often with the police responsible for the initial investigation.

The distribution of the fatal accidents due to collisions of cars and lorries and the period of each part of the survey are shown in table I. The 224 car occupant deaths from car/lorry collisions were taken from our total study of 564 car occupant deaths from all types of accident on the same roads and over the same periods. Thus $40 \%$ of the car occupant deaths in our samples have been due to car/lorry collisions. On the London to Birmingham stretch of M.1 and M.45 fatalities to car occupants from car/lorry collisions accounted for twice the number of deaths as those from car/car collisions, on M.6 and M.62 for over three times the numbers, and on link roads twice the numbers. Only on the rural roads of Warwickshire and the urban roads of Birmingham did the fatalities from car/car collisions exceed those from cars and lorries. Since the nature of the collisions differed on the types of road, each will be considered separately. Common to all areas was the gross severity of the injuries to car occupants, chiefly affecting the head and trunk in various combinations as shown in table II.

These fatal injuries were predominantly caused by deformation or penetration of the car's passenger compartment, causing impacts on body areas above the level of the car seat. As shown in table III, the severity of injuries was such that a very high proportion of the victims died at the accident site or on their way to hospital.

\section{Fatal Collisions on Motorways}

Motorways have many built-in safety features, notably central reservations separating traffic trovelling in different directions, overtaking lanes distinguished by white lines, hard shoulders for emergency stops, and service facilities well away from the traffic lanes with well-defined entries and exits for use only in the line of traffic flow. Through design, all cross traffic is eliminated, and by law pedestrians, pedal cyclists, and learner drivers are prohibited. Thus many types of collision common on other 
TABLE I-Distribution of 224 Car Occupant Fatalities from Car/Lorry Collisions

\begin{tabular}{|c|c|c|c|c|c|c|c|c|c|c|}
\hline \multirow{3}{*}{ Road } & \multirow{3}{*}{ Period } & \multicolumn{3}{|c|}{$\begin{array}{l}\text { Vehicles Travelling in } \\
\text { Same Direction }\end{array}$} & \multicolumn{3}{|c|}{$\begin{array}{l}\text { Vehicles Travelling in } \\
\text { Different Directions }\end{array}$} & \multicolumn{3}{|c|}{ Total } \\
\hline & & \multirow[b]{2}{*}{ Accidents } & \multicolumn{2}{|c|}{ Deaths } & \multirow[b]{2}{*}{ Accidents } & \multicolumn{2}{|c|}{ Deaths } & \multirow[b]{2}{*}{ Accidents } & \multicolumn{2}{|c|}{ Deaths } \\
\hline & & & $\begin{array}{c}\text { Car } \\
\text { Occupants }\end{array}$ & $\begin{array}{c}\text { Lorry } \\
\text { Occupants }\end{array}$ & & $\begin{array}{c}\text { Car } \\
\text { Occupants }\end{array}$ & $\begin{array}{c}\text { Lorry } \\
\text { Occupants }\end{array}$ & & $\begin{array}{c}\text { Car } \\
\text { Occupants }\end{array}$ & $\begin{array}{c}\text { Lorry } \\
\text { Occupants }\end{array}$ \\
\hline $\begin{array}{l}\text { Motorways: } \\
\left.\begin{array}{l}\text { M.1 } \\
\text { M.45 }\end{array}\right\} 78 \mathrm{~m}(125 \mathrm{~km}) \\
\left.\begin{array}{l}\text { M.6 (part) } \\
\text { M.62 }\end{array}\right\} 72 \mathrm{~m}(116 \mathrm{~km})\end{array}$ & 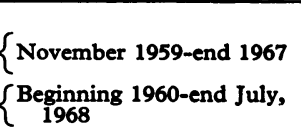 & 41 & 56 & 一 & 18 & 27 & - & 59 & 83 & - \\
\hline $\begin{array}{l}\text { Link Roads: } \\
\left.\begin{array}{l}\text { A.6 } \\
\text { A.74 }\end{array}\right\} 56 \mathrm{~m}(90 \mathrm{~km}) \\
\left.\begin{array}{l}\text { A.580, } 30 \mathrm{~m}(48 \mathrm{~km}) \\
\text { A.584 (part), } 35 \mathrm{~m}(56 \mathrm{~km})\end{array}\right\}\end{array}$ & $\begin{array}{l}\{\text { Beginning } 1960 \text {-end } 1967 \\
\text { Beginning } 1960 \text {-end July, } \\
1968\end{array}$ & 15 & 17 & 1 & 53 & 58 & 3 & 68 & 75 & 4 \\
\hline $\begin{array}{l}\text { Rural Roads: } \\
\text { Central and s.w. } \\
\text { Warwickshire }\end{array}$ & November, 1959-end 1964 & 7 & 7 & - & 30 & 42 & 1 & 37 & 49 & 1 \\
\hline $\begin{array}{c}\text { Urban Roads: } \\
\text { Birmingham } \\
\end{array}$ & Beginning 1960-end 1961 & 7 & 7 & 一 & 10 & 10 & 一 & 17 & 17 & $\mathbf{0}$ \\
\hline Total & & 70 & 87 & 1 & 111 & 137 & 4 & 181 & 224 & 5 \\
\hline
\end{tabular}

For the purpose of this study all goods vehicles of $\mathbf{3 0} \mathrm{cwt}$ or more unladen weight are classed as lorries. Taxis and light vans are classed as cars.

TABLE II-Distribution of Parts of Body Injured in Car Occupant Deaths from Car/Lorry Collisions

\begin{tabular}{ll|c|c|c}
\hline \multicolumn{1}{c|}{ Injuries } & $\begin{array}{c}\text { Vehicles Travel- } \\
\text { ling in same } \\
\text { Direction }\end{array}$ & $\begin{array}{c}\text { Vehicles Travel- } \\
\text { ling in Different } \\
\text { Directions }\end{array}$ & Categories \\
\hline Involving head & $\cdots$ & $89 \%$ & $87 \%$ & $87 \%$ \\
Involving chest & $\cdots$ & $57 \%$ & $80 \%$ & $71 \%$ \\
Involving abdomen & $\cdots$ & $31 \%$ & $70 \%$ & $54 \%$ \\
Involving lower limbs & $12 \%$ & $35 \%$ & $25 \%$ \\
Other..$\quad \cdots$ & $\cdots$ & $8 \%$ & $12 \%$ & $10 \%$ \\
\hline
\end{tabular}

TABLE III-Time of Death after Accident-Car Occupants Killed after Collisions with Lorries

\begin{tabular}{|c|c|c|c|c|c|c|}
\hline \multirow[b]{2}{*}{ Road } & \multicolumn{6}{|c|}{ Time of Death } \\
\hline & $\begin{array}{l}\text { Immedia- } \\
\text { tely or } \\
\text { Before } \\
\text { Reaching } \\
\text { Hospital }\end{array}$ & $\begin{array}{l}\text { Hospital } \\
\text { Admis- } \\
\text { sion < } \\
6 \text { Hours }\end{array}$ & 6 Hours & $\stackrel{24}{\text { Hours }+}$ & $\underset{\text { Known }}{\text { Not }}$ & Total \\
\hline $\begin{array}{ll}\text { Motorways } & \ldots \\
\text { Link roads } & \ldots \\
\text { Rural roads } & \ldots \\
\text { Urban roads } & . .\end{array}$ & $\begin{array}{r}61 \\
49 \\
22 \\
2\end{array}$ & $\begin{array}{r}11 \\
9 \\
16 \\
5\end{array}$ & $\begin{array}{l}4 \\
2 \\
4 \\
4\end{array}$ & $\begin{array}{l}5 \\
9 \\
7 \\
5\end{array}$ & $\begin{array}{l}2 \\
6 \\
\overline{1}\end{array}$ & $\begin{array}{l}83 \\
75 \\
49 \\
17\end{array}$ \\
\hline Total & 134 & 41 & 14 & 26 & 9 & 224 \\
\hline
\end{tabular}

roads should not occur. The high speeds encouraged by these conditions, however, lead to very severe injuries if collisions do occur.

FATAI COLLISIONS WHEN CARS AND LORRIES WERE TRAVELIING IN THE SAME DIRECTION

There were 34 collisions of cars into the rear of lorries with 48 car occupant deaths and no recorded injuries to lorry drivers. Twenty-six collisions occurred on the inside lane or hard shoulder, four in the middle lane, and four in the outside lane. That so many collisions occurred on the inside lane or hard shoulder required further investigation. Of the 26 lorries, 18 were either stationary or moving slowly; some of them had mechanical defects, some were labouring up gradients. Six of the stationary ones were on the hard shoulder either because of mechanical problems or their driver's need for rest-two of the drivers admitted being asleep.

These collisions by cars into lorries moving slowly or even standing still on the hard shoulder are particularly difficult to understand. The damage to the vehicle suggests that the drivers recognized too late the impending collision and at the last moment pulled over to the offside. Consistent with this is our finding that of those exposed, a higher proportion of front seat passengers were killed than drivers. Altogether, 19 of the collisions occurred at night and none were in lighted sections of the motorway. Of the four collisions in the middle lane, two drivers of heavily-laden lorries suddenly pulled out of the inner lane to avoid colliding into the rear of a much slower lorry and once in the middle lane were struck by a much faster-moving car. In two collisions in the outside lane the lorry drivers broke motorway regulations by making $U$ turns. Another lorry driver came to a halt in the outside lane after wandering between lanes; he was awakened when the fatal collision occurred. The final outside lane collision between a car and the rear of a lorry occurred when the motorway was temporarily reduced to two lanes and the driver of a much faster-moving car underestimated its closing speed on a wet road, suddenly braked, but still skidded into the lorry. Seven of the eight collisions of cars into the rear of lorries on the middle and outer lanes occurred in darkness on unlit motorways.

Relating the injuries of occupants to the damage of their cars, we have attributed 32 of the $\mathbf{4 8}$ deaths as due to penetration of the car's windscreen area by the rear overhang of the lorry (see fig. 1). A further 11 deaths were due to deformation of the front section of the passenger compartment after collisions with lorries or heavy vans without the dangerous rear overhang. In one car, after its collision with the flat rear end of a large van,

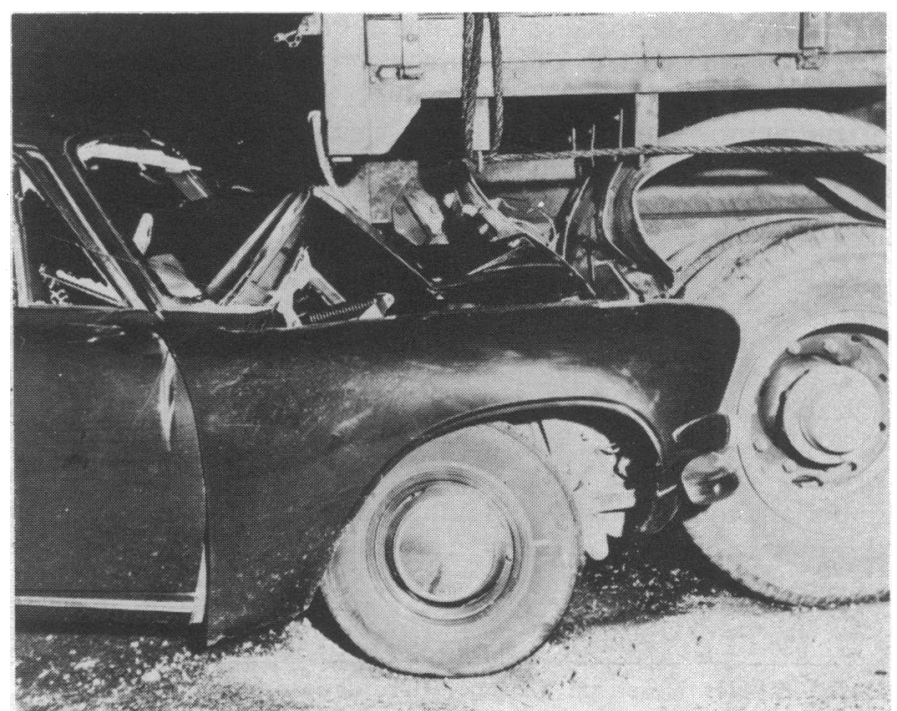

FIG. 1-Illustrating danger of even a small rear overhang of lorry. Car's windscreen was penetrated and its driver killed, but car had rebounded when picture was taken. 
the deformation of the car trapped its three occupants, a loose full tin of petrol with a faulty cap carried on the back seat spilled and ignited, and the three occupants, all of whom had been smoking, were incinerated. The remaining two deaths occurred in relatively undeformed passenger compartments and would have been prevented if seat belts had been worn.

The 32 fatal cases due to penetration of the cars by the rear overhang of lorries had a combination of injuries unequalled in severity by any other type of collision we have investigated. There were severe and multiple fractures of skull and face with associated gross brain damage, and extremely severe types of injuries to the neck including one complete decapitation, severe crushing injuries to the chest involving the heart, its great vessels, the lungs, and major air passages. No restraining equipment, whether safety belts or air bags, could offer adequate protection against the deformation and penetration caused by the rear overhang of lorries or their protruding loads in a highspeed collision.

Lorries Colliding into the Rear of Cars.-There were seven such collisions on motorways resulting in eight deaths to car occupants and no injuries to lorry occupants. Special circumstances appear to be necessary for the usually slower-moving lorries to collide into the rear of cars on motorways. Five of these collisions occurred in the hours of darkness in dense traffic conditions, the remaining two occurred in fog when many vehicles were involved, and in addition to the two deaths many more people suffered serious injuries.

One noteworthy feature of lorries colliding into the rear of cars has been fire following damage to the car's petrol tanks. Three of the eight deaths recorded have been associated with extensive burns made worse by the trapping of these occupants in their deformed cars. We have attributed three other deaths as due purely to deformation of the passenger compartment, and the final two to unbelted occupants being first thrown about in a relatively intact car and then ejected from it.

FATAL COLLISIONS BETWEEN CARS AND LORRIES WHEN TRAVELLING IN DIFFERENT DIRECTIONS

For such collisions under normal motorway conditions vehicles must either cross the central reservation or enter the motorway in the wrong direction. There were 18 collisions on motorways between cars and lorries travelling in different directions with 27 car occupant deaths and three minor injuries to lorry occupants.

On 13 occasions cars crossed the central reservation-bald or burst tyres associated with high speeds were contributory factors in five, and in seven cases wet and icy roads were recorded. On two occasions car drivers entered the motorway in the wrong direction. One was a driver under treatment for a mental illness, and the other was an aged driver who lost his way -he had "never been near a motorway before."

Three lorries got into the line of oncoming traffic. One a heavy and heavily-laden articulated vehicle, after braking hard on a wet road surface, lost control, crossed the central reservation and came to a halt, jacknifed broadside and blocked all lanes of the opposite carriageway causing one fatal and many serious injuries to the occupants of cars. Another lorry driver had made an illegal $U$ turn. The final collision occurred when all southbound lanes were temporarily closed and the section reverted to the design of other roads.

We have attributed 21 car occupant deaths as due to deformation of the passenger compartment and six to occupants being thrown out of relatively intact passenger compartments. No car occupant was wearing a seat belt.

\section{Fatal Collisions on Link Roads}

These roads take a heavy load of mixed traffic directly off motorways. Though redesigned for motor traffic they lack most of the built-in safety features of motorways. On these roads there were
68 fatal collisions resulting in 75 car occupant deaths, three deaths to lorry drivers were caused by subsequent related accidents. For a similar period of study there were more of these fatal accidents on the link roads than on the motorways, though the link roads had $20 \%$ less mileage and less heavy traffic.

FATAL COLLISIONS BETWEEN CARS AND LORRIES TRAVELLING IN DIFFERENT DIRECTIONS

Since most of these roads had no central reservation, collisions between vehicles travelling in opposite directions far outnumbered all others-there being 53 such collisions resulting in 58 car occupant deaths and three to lorry drivers. Cars were often over the crown of the road during overtaking or after taking sharp bends at high speed. Other collisions occurred at road junctions. On three occasions lorry drivers crossed the line of oncoming traffic while entering or leaving service stations on their opposite side-a permitted though dangerous practice that resulted in three fatal collisions.

The three fatalities to lorry drivers were not caused directly by their collision with cars but from the loss of control of the lorry followed by another accident sequence. For example, after colliding with a car an articulated lorry jacknifed then overturned and its displaced heavy and loose load contributed to the crushing of its cab and the fatal injuries to its driver.

Of the 58 car occupants killed, 36 were drivers, 13 were front seat passengers and nine were in the rear of the vehicle.Thirtynine of the deaths were caused by deformation of the car's passenger compartment crushing head, chest, and abdomen in various combinations of injury. In the remaining 19 cases the passenger compartments were relatively intact, and seat belts, had they been worn, would have given some protection.

FATAL COLLISIONS BETWEEN CARS AND LORRIES TRAVELLING IN THE SAME DIRECTION

There were 15 such collisions resulting in 17 car occupant deaths and one death of a lorry driver. Fourteen cars collided into the rear of lorries and one lorry collided into the rear of a stationary car. Twelve of the collisions occurred in the hours of darkness in areas with poor or absent road lighting. On 11 occasions the lorry was stationary on the nearside of the road and on two occasions moving very slowly preparatory to entering nearside service stations-both with narrow parking areas entered directly off the road. Three fatal collisions had noteworthy features. (1) In daylight but in a heavy wind, an insecurely-fastened tarpaulin covering a lorry's loose load blew off and went down the road like a sail. It completely blocked the forward view of a following car whose driver turned sharply to her nearside, and she received fatal injuries from impact with the rear of another parked lorry. (2) At night, a $44 \mathrm{ft}(13 \mathrm{~m})$-long articulated lorry had halted at a crossing on a dual carriageway, leaving a large section of its rear projecting across the outside lane of the carriageway it was leaving. In this position its rear lights were not visible to an oncoming fast-moving car, with fatal consequences to its driver. (3) In daylight but in heavy rain and on a steep downhill gradient, an articulated tanker (gross weight 24 tons) rounded a bend and its driver then became aware of temporary traffic lights for emergency road repair work less than 70 yards ahead and a line of stationary vehicles. He braked hard and skidded into the rearmost car (see fig. 2).

Of the 14 fatal collisions of cars into the rear of lorries, 12 were into lorries with the dangerous rear overhang, and the 16 deaths resulting were due to penetration of the car's windscreen area with injuries characteristic of such penetration. Four fatal collisions were into lorries without the rear overhang, and caused gross deformation of the car's passenger compartment; in two others the passenger compartment was relatively undeformed and if seat belts had been worn the occupants might well have survived. 


\section{Fatal Collisions on Rural Roads (Warwickshire)}

These roads varied in design and suitability for mixed traffic. Some were " $A$ " type roads, others were narrow rural roads with many undulations and sharp bends-the latter sometimes leading onto narrow bridges and quite unsuitable for the usual speeds of motor vehicles. Roadside hedges and large trees often obscured the nature of the bends and the traffic ahead. On these roads deaths from collisions between cars were twice as frequent as those from car/lorry collisions. Compared with motorways and link roads, they are less used by lorries. Yet on these roads, over a five-year period, there were $37 \mathrm{car}$ collisions with lorries resulting in 49 deaths to car occupants (fig. 3 ) and one death to a lorry driver.

FATAL COLLISIONS BETWEEN CARS AND LORRIES TRAVELLING IN DIFFERENT DIRECTIONS

There were 30 such collisions with 42 deaths to car occupants and one to a lorry driver. Sixteen occurred on " $A$ " roads with 23 deaths, and 14 occurred on other types of road with 19 deaths. In 25 of the collisions cars were over the crown of the road when overtaking, in nine cases cars were taking sharp bends at too high a speed, and in five cases lorries got into the line of oncoming traffic. In one of these the comparatively young driver of a cattle transporter lost control of his vehicle during the onset of a fatal heart attack and collided with a car, resulting in the deaths of its three occupants. Another accident occurred on a narrow rural bridge incapable of accommodating the large lorry crossing it and a small car which attempted to do so after negotiating a bend which obstructed its driver's view of the lorry.

Of the 30 car drivers $25(83 \%)$ were killed, $17(59 \%)$ of the front seat passengers at risk died, as did $6(46 \%)$ of the rear seat occupants. The car occupant deaths were predominantly due to the deformation of their cars; the one lorry driver's death was caused by deformation of the lorry's cab. Yet 14 deaths occurred in comparatively undeformed cars and probably would have been prevented if these occupants had been wearing seat belts. Two other deaths occurred in a car which caught fire after a head-on collision with a lorry. The car was fitted with an electric-powered petrol pump which continued to function after the collision and apparently contributed to the fire and the deaths from burns of its occupants.

FATAL COLLISIONS BETWEEN CARS AND LORRIES TRAVELLING IN THE SAME DIRECTION

Seven such collisions occurred, causing seven car occupant deaths and no injuries to lorry drivers. On six occasions cars collided with the rear of lorries-four on minor roads and two on " $A$ " roads; in one incident a lorry collided with the rear of a

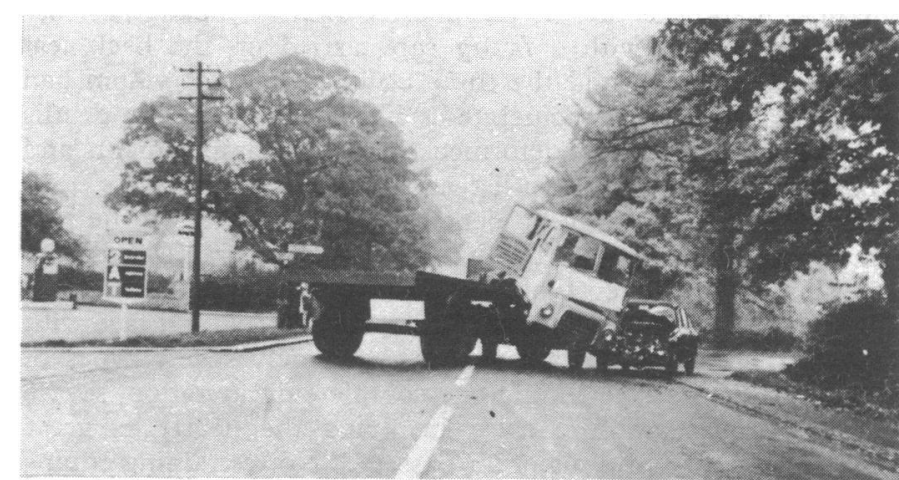

FIG. 3-This articulated lorry "jacknifed" when attempting a right hand turn, and suddenly caused an obstruction into which a car collided resulting have occurred.

car at a road junction. Six of the seven collisions occurred during the hours of darkness. All deaths were attributed to the deformation of the cars.

\section{Fatal Collisions on Urban Roads (Birmingham)}

On these urban roads collisions between cars and lorries as a cause of road deaths ranked well below those to pedestrians from car/pedestrian collisions and to car occupants from collisions between cars. Yet in our two-year survey there were $17 \mathrm{col}-$ lisions between cars and lorries resulting in 17 car occupant deaths and no injuries to lorry occupants, 10 when the vehicles were travelling in different directions and seven when travelling in the same direction. Eight of the collisions occurred at night, and street lighting was recorded at the time as "good." However, when driving around the sites of these accidents at night one often found confusing shadows cast by street lighting, and in different areas lights differed greatly in colour and intensity.

Three collisions occurred at or near road junctions and one on a roundabout, the others were on straight sections of road. In the 10 collisions between vehicles travelling in different directions cars were invariably over the crown of the road, generally when overtaking and less frequently from skidding on wet or icy surfaces.

Of the seven fatal collisions between cars and lorries travelling in the same direction, four were at night, the lorries concerned being stationary. Confusing shadows may have been a contributory cause in three, and in one a car driver had a blood alcohol level of $245 \mathrm{mg} / 100 \mathrm{ml}$. One of these deaths was that of a car driver who was thrown out of his vehicle when it was struck in the rear by a lorry.

Of the 17 deaths in urban car/lorry collisions, 12 have been attributed to deformation of the passenger compartment and the remainder to being thrown about or ejected from relatively

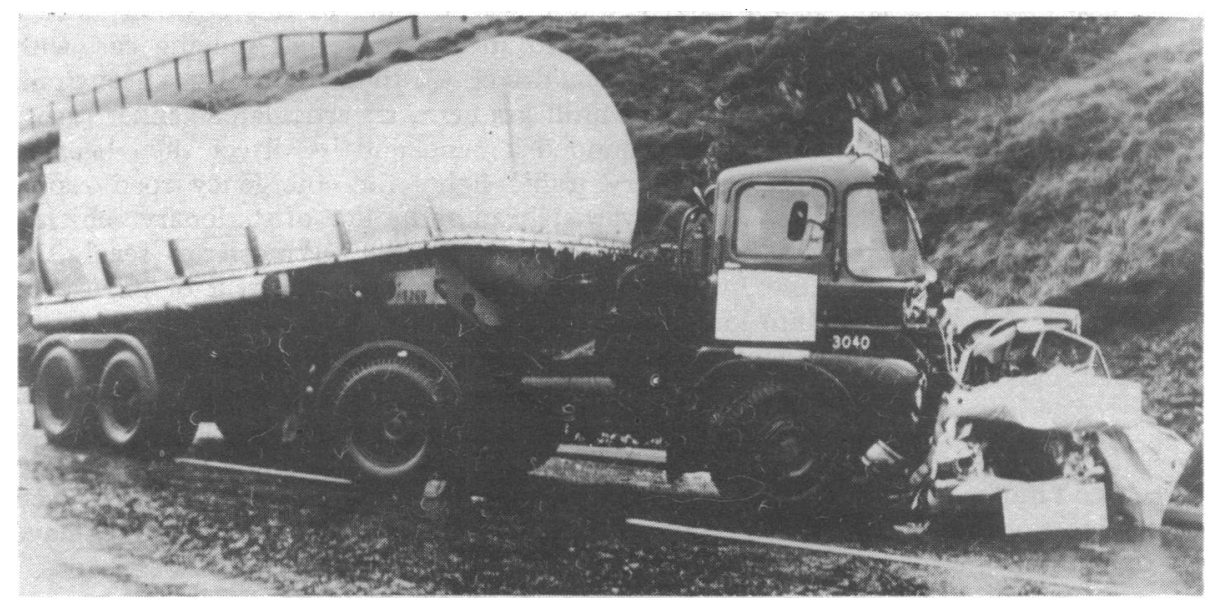

FIG. 2-When a "heavyweight" collides with a "lightweight" the occupants of the latter vehicle are almost invariably the victims. 
undeformed cars. Again no occupant was wearing a seat belt. Good protection would have been given to five.

\section{Discussion}

National figures are not available for the numbers of deaths due to collisions of cars and lorries. Among 296 deaths of car occupants within 12 hours of injury, Ruffel Smith (1970) found that more than half were due to collisions with lorries. In our present series of 564 car occupant deaths $40 \%$ were from such collisions. It is difficult to apply appropriate weightings for different traffic conditions, but if $40 \%$ is a fair estimate it implies that in Great Britain car/lorry collisions cause about 1,000 deaths annually. This is as many as all the deaths due to accidents at work as studied by the recent Robens inquiry (Secretary of State for Employment, 1972).

At first sight it is surprising that these collisions should be so common since lorries are outnumbered by cars by $7-1$. The explanation seems to be an incompatability between the two types of vehicle. The lorry is heavy and strongly built to carry heavy loads. Rising gradients slow it down, falling gradients may cause it to go out of control. The car by contrast is light and built to maintain high speeds with light loads. Grime (1971) studied the theoretical mechanics of impacts between vehicles of different sizes. Of the lorries in our survey of which we know the weights, more than half were over 5 tons unladen. Most of the collisions, therefore, had a "mass-ratio" of at least 5 . In Grime's analysis this implies a $95 \%$ or more risk of serious injury to car occupants with virtually no risk to the lorry occupants. This is consistent with our finding of 224 deaths of car occupants with five deaths of those in lorries.

The unfavourable terms of this conflict has important implications for methods of protection. Whereas several studies show that seat belts will prevent $50 \%$ of injuries to car occupants, in our car/lorry collisions we estimate this could be only about $20 \%$. The figure falls to about $10 \%$ for collisions of cars into the rear of lorries where so often the rear overhang or protruding load penetrates the windscreen area and so eliminates the protection normally afforded by the front of the car.

Collisions into the rear of lorries are several times more frequent in dark than in light conditions in spite of there being less traffic of all kinds at night. This suggests there is room for improvement in making lorries more conspicuous. The current experiment with extra coloured markings may yield some benefit and there could well be other ways to warn motorists of impending danger. Elimination of the rear overhang of lorries and improved lighting might prevent some of the worst collisions but the underlying incompatibility of light and heavy vehicles remains. A more fundamental solution is the segregation of the two types of traffic on separate roads as on some highways in the United States. Another solution, perhaps more appropriate to this country, is to take account of the impending world shortage of oil supplies and save both fuel and human lives by using rail rather than road transport.

We wish to thank Miss B. Roberts, for her help in this analysis, and the coroners and police of the areas studied, for their kind co-operation.

The earlier part of this study was supported by a grant from the Automobile Association, but the recommendations are the sole responsibility of the authors.

\section{References}

Grime, G. (1971). Effect of Vehicle Mass on Risk of Injury in a Collision. London, University College.

Ruffell Smith, H.P. (1970). A Study of Fatal Injuries in Vehicle Collisions Based on Coroners' Reports. LR 316 . Crowthorne, Road Research Laboratory. p. 161 . London, H.M.S.O.
.

\section{Immunological Abnormalities in Juvenile Myelomonocytic Leukaemia}

\section{ARLETTE CANNAT, MAXIME SELIGMANN}

British Medical fournal, 1973, 1, 71-74

\section{Summary}

Immunological studies were performed on 24 children suffering from juvenile myelomonocytic leukaemia. Strikingly high serum immunoglobulin levels with a frequent tendency towards homogeneity and light-chain imbalance were present, together with a high incidence of antinuclear antibodies (52\%) and antihuman IgG antibodies $(43 \%)$. Members of the families of 19 of the children were also studied. A few similar abnormalities were found in eight families, mostly clustered in four of them. The significance of the association of these immunological aberrations with juvenile myelomonocytic leukaemia is at present unknown. In view of the interrelation observed in experimental models between immunological abnormalities and oncogenic viruses the possibility of a common aetiological factor such as a viral infection during fetal life is suggested.

\footnotetext{
Department of Immunochemistry, Research Institute on Blood Diseases, Hôpital Saint-Louis, Paris 10e, France ARLETTE CANNAT, M.D., Maître de Recherches à I'I.N.S.E.R.M. MAXIME SELIGMANN, M.D., Professor
}

\section{Introduction}

Juvenile myelomonocytic leukaemia is an uncommon condition, and should be regarded as a separate entity from the chronic granulocytic leukaemia of adult type which may occur in childhood (Bernard et al., 1962). The two diseases differ in many clinical and haematological features. The myelomonocytic type occurs in infants and very young children, and is usually characterized by greater lymph node enlargement, frequent cutaneous manifestations which may be of xanthomatous type, early onset of thrombocytopenia, lower total leucocyte count with fewer myelocytes but a higher proportion of monocytes, hypochromic anaemia, and presence of normoblasts in the peripheral blood. The absence of the Philadelphia chromosome in the bone marrow cells of these children (Reisman and Trujillo, 1963; Hardisty et al., 1964) provides strong support for regarding juvenile myelomonocytic leukaemia as different from chronic myeloid leukaemia. The extreme variability of the course, together with the unpredictable prognosis in children affected with this condition, raise the possibility that it is not a single disease entity (Bernard and Seligmann, 1968).

A number of peculiar biological features such as very high blood levels of fetal haemoglobin (Hardisty et al., 1964; Miller, 1969), modifications of blood group antigens, and hypergammaglobulinaemia (Bernard and Seligmann, 1968) are frequently found in these children. Whereas high levels of $\mathrm{Hb} \mathrm{F}$ are found mainly in cases with poor prognosis, hypergammaglobulinaemia is an almost constant feature of this condition whatever its 